DOI: https://doi.org/10.24867/12CG08Jelic

\title{
МЕТОДОЛОГИЈА ПРОРАЧУНА ГАБИОНСКИХ ПОТПОРНИХ ЗИДОВА ПРЕМА ЕВРОКОДУ 7
}

\section{METHODOLOGY FOR CALCULATING THE STABILITY OF THE GABION RETAINING WALL ACCORDING TO EUROCODE 7}

\author{
Петар Јелић, Факултет техничких наука, Нови Сад
}

\begin{abstract}
Област- ГРАЂЕВИНАРСТВО
Кратак садржај - $У$ оквиру рада објашњена је методологија прорачуна стабилности габионских потпорних зидова према еврокоду 7. Прорачун габионског зида врии се према еврокоду 7 у оквиру кога су дефинисана 3 пројектна приступа према граничним станима носивости (STR+GEO). Прорачун стабилности габионског зида је урађен према прорачунском приступу 2*, код кога се парцијални коефицијенти наносе на силе и отпоре, али тек на крају прорачуна, тако да се он, у највећем делу, одвија применом карактеристичних вредности, као што је код нас била пракса. На деоници Косјерић - Пожега, стационаже од км 183+075 до км 205+210 (дужине 22. $135 \mathrm{\kappa м}$ ), Због пројектованог проширења пута $и$ пројектоване пешачке стазе у зони раскрснице Косјерић (жел.станица), а због недостатка простора да се изведе насип, у зони ножице насипа са десне стране пута, дато је решење $y$ виду габионског зида. $У$ оквиру прорачуна стабилности раде се следеће анализе: анализа стабилности потпорног зида на претурање, анализа стабилности потпорног зида на клизање, анализа напрезања тла у контактној површи,носивосттла. Прорачун је урађен ручно, као и применом софтверског пакета GEO 5. (Програм Gabion).
\end{abstract}

Кључне речи: Габионски зид, методологија, прорачун стабилности, еврокод 7.

Abstract - The methodology of calculating the stability of gabion retaining walls according to Eurocode 7 is explained in the paper. The calculation of the gabion wall is done according to Eurocode 7, within which 3 project approaches are defined according to the bearing capacity limit states $(S T R+G E O)$. The calculation of the stability of the gabion wall is done according to the design approach $2 *$, when partial coefficients are applied to forces and resistances, but only at the end of the calculation, so that it, for the most part, takes place using characteristic values, as it was our practice. A solution in form of a gabion wall was given on the road section Kosjerić - Požega, regarding the chainage from $\mathrm{km} 183+$ 075 to $\mathrm{km} 205+210$ (22. $135 \mathrm{~km}$ long), due to the designed road widening and the designed footway in the area of the intersection Kosjerić (railway station) and due to lack of space to make an embankment, in the area of

\section{НАПОМЕНА:}

Овај рад проистекао је из мастер рада чији ментор је био доц. др Милош Шешлија. of the bottom of the embankment on the right side of the road. Based on soil testing, the parameters required for stability analysis are obtained. The following analyzes are performed within the stability calculation:analysis of the retaining wall stability to overturning, analysis of the retaining wall stability to sliding, analysis of soil stress at the contact surface, bearing capacity of soil. The calculation was done manually, as well as using the GEO 5 software system (Gabion Program).

Key words: Gabion wall, methodology, calculating the stability, eurocode 7.

\section{1. ГРАНИЧНА СТАҢА НОСИВОСТИ (ЕК7 )}

Постоји 5 граничних стања носивости, од којих су за потребе мастер рада разматрана прва три.

EQU (equilibrium - ravnoteža) је губитак равнотеже конструкције или тла посматраног као круто тело, у случајевима када чврстоће материјала конструкције и темељног тла нису битне за отпорност,

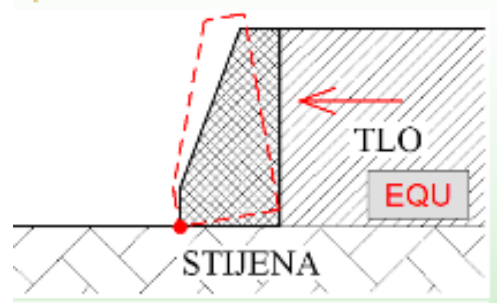

Слика 1 EQU - Гранично стање

STR (structural - konstrukcijski) је лом или велика деформација бетонске, металне, дрвене или зидане конструкције или њеног елемента, укључујући темеље, шипове, сидра и потпорне зидове, у којима чврстоћа конструктивног материјала битно доприноси отпорности

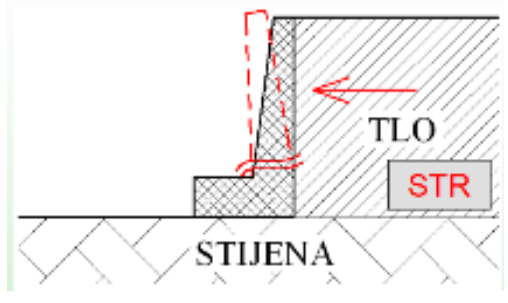

Слика 2 STR - Гранично стане

GEO (geotechnical - геотехнички) је лом или велика деформација тла при којој чврстоћа тла или стене битно доприноси отпорности, (лом тла испод темеља, лом тла око хоризонтално оптерећеног шипа, велико слегање шипа, нагињање потпорног зида, чупање 
сидра из тла, лом и пропадање тла изнад тунелског ископа, клизање и одрон тла, значајно попуштање ослонца лука моста, издизање и лом дна темељне јаме у меком тлу).

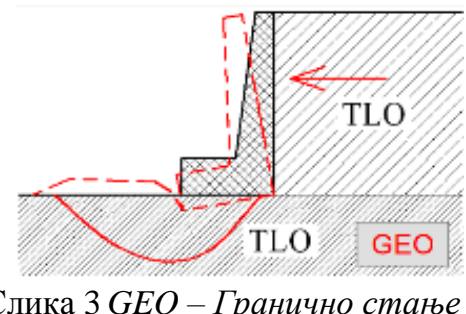

Слика 3 GEO - Гранично стање

\section{2. ИЗБОР ПРОРАЧУНСКОГ ПРИСТУПА ( ПП2*)}

Еврокод нам нуди три прорачунска приступа, односно поступка димензионисања геотехничких конструкција. Постигнута компатибилност старих и нових метода прорачуна, води ка одабиру прорачунског приступа који ће инжењери користити. Пракса је показала успешност примењивања постојећих поступака и коефицијената и доказала их вишедеценијском употребљивошћу објеката. Наиме, у изворном поступку 2, ПК се наносе дејствима већ на почетку, због чега се и анализа врши с прорачунским вредностима, што, међутим, води у одређену нелогичност у погледу носивости, па је припремљена алтернатива у виду ПП2*, где се највећи део прорачуна спроводи се карактеристичним вредностима јер се ПК прикључују тек у завршници анализе.

У поступку 2 примењују се фактори на отпоре, што га чини примамљивим за усвајање. Али, главно оптерећење које стално делује на потпорне зидове јесте земљани притисак који је, између осталог, у функцији од чврстоће тла, а она зависи од оптерећења, па је зато важно да се код његовог одређиванја не врши множење оптерећења са ПК. У супротном, резултирало би модификацијом притиска без могућности његове даље контроле, нарочито приликом анализа у МКЕ, што захтева да се прорачуни спроводе с њиховим карактеристичним вредностима, чиме се из избора избацује ПП2, али не и ПП $2 *$, јер управо он омогућава такав прорачун.

Ово наликује актуелној пракси, а положај ПК у једначинама ионако подсећа на глобални фактор сигурности. Дакле, како би били доследни традицији када се користе изворне величине сила и на крају упоређују отпори, пожељни ПП лоцира се у оном са ознаком 2*, код кога се ПК наносе на силе и отпоре, али тек на крају прорачуна, тако да се он, у највећем делу, одвија применом карактеристичних вредности, као што је код нас било и досада.

Оно што такође охрабрује јесте то што је највише земаља за димензионисанје потпорних зидова препоручило управо наведени приступ. То је приступ који је предложила Немачка, а који се заснива на искуству од 80 година пројектовања без ломова, па је стога близак корисницима,што важи и за наш регион. На основу наведених разлога, ПП 2* позитивно је оцењен и препоручен за аналитички прорачун зидова према EK7.

\section{3. СТАБИЛНОСТ ГАБИОНСКИХ ПОТПОРНИХ КОНСТРУКЦИЈА ПРЕМА ЕВРОКОДУ 7}

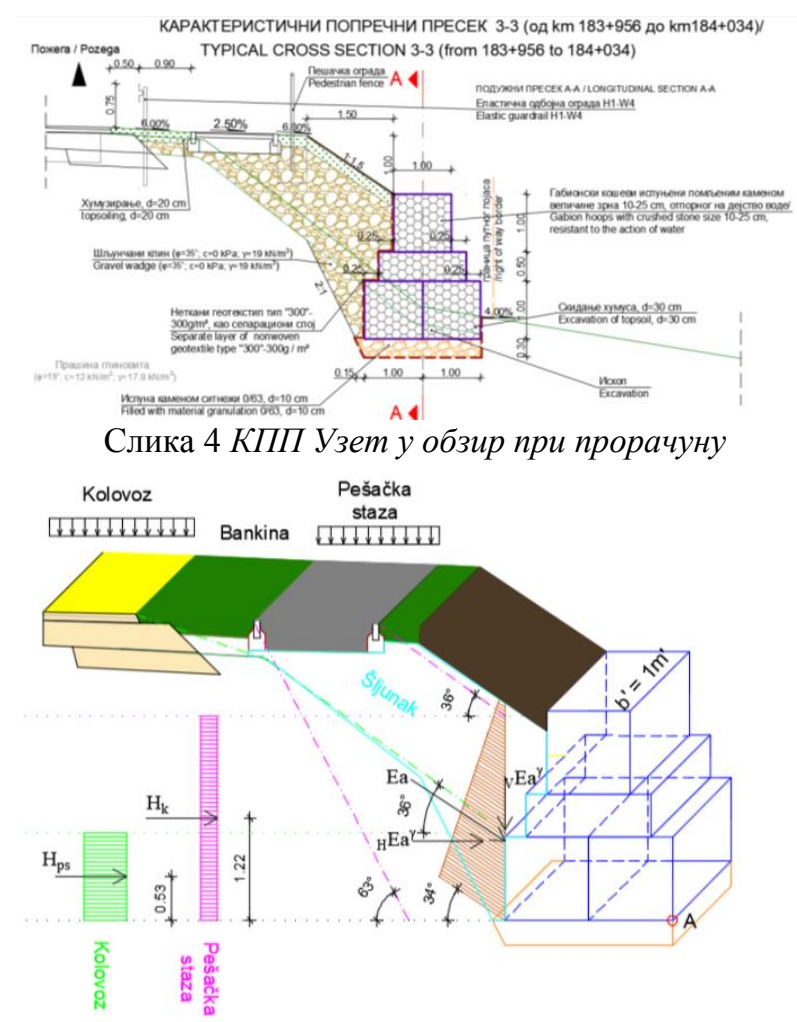

Слика 5 Скица зида и шема оптерећења

У складу са националним анексом за Еврокод 7, део 1, y Републици Србији се при разматрању граничних стана за потпорне конструкиије користи прорачунски приступ 2, са парцијалним факторима сигурности приказаним у следећој табели.

Табела 1 Париијални фактори сигурности за пројектни приступ 2

\begin{tabular}{|c|c|c|c|}
\hline$\gamma$ & \multicolumn{2}{|c|}{ projektni pristup 2} & Parametar na koji se odnosi \\
\hline & povoljno & 1.0 & \multirow{2}{*}{ Stalno dejstvo } \\
\hline & nepovoljno & 1.35 & \\
\hline \multirow[b]{2}{*}{$\gamma_{Q}$} & povoljno & 0 & \multirow{2}{*}{ Povremeno dejstvo } \\
\hline & nepovoljno & 1.5 & \\
\hline$\gamma_{f}$ & \multicolumn{2}{|c|}{1.0} & Ugao unutrašnjeg trenja za efektivne napone \\
\hline$\gamma_{c}$ & \multicolumn{2}{|c|}{1.0} & Kohezija za efektivne napone \\
\hline$y_{x}$ & \multirow{2}{*}{\multicolumn{2}{|c|}{$\begin{array}{l}1.0 \\
1.4\end{array}$}} & Zapreminska težina tla \\
\hline 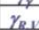 & & & Nosivost temeljnog tla \\
\hline$\gamma_{B H}$ & \multicolumn{2}{|c|}{1.1} & Otpornost na klizanje po temeljnoj spojnici \\
\hline
\end{tabular}

Према прорачунском приступу $2 *(\mathrm{PP} 2 *)$, прорачун се спроводи са карактеристичним вредностима параметара, парцијални коефицијенти (ПК) се наносе на силе и отпоре на крају прорачуна.

\section{1 Контрола стабилности на претурања}

Анализа потпорног зида на претурање, спроводи се за гранична стања носивости - губитка равнотеже конструкције, EQU.

Потребно је да буде задовољена следећа релација: $\mathbf{M}_{\mathbf{d s t}, \mathbf{d} \leq} \mathbf{M}_{\mathrm{stb}, \mathbf{d}}$

где je $\mathrm{M}_{\mathrm{dst}, \mathrm{d}}$ моменат свих дестабилизујућих (неповољних) сила око тачке О (ножица потпорне конструкције), a $\mathrm{M}_{\text {stb,d }}$ моменат повољних сила које спречавају превртање. ( Слика 4) 


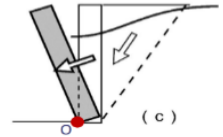

Слика 6 Тачка претурања зида
Слика 7 моменти око тачке $\mathrm{O}$

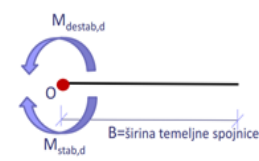

Дестабилишући момент је последица хоризонталног притиска тла и хоризонталног притиска услед оптерећења q на површини тла.

$\mathrm{M}_{\mathrm{dst}, \mathrm{d}}=1.1 \cdot \mathrm{P}_{\mathrm{t}} \cdot \mathrm{e}_{\mathrm{t}}+1.5 \cdot \mathrm{P}_{\mathrm{q}} \cdot \mathrm{e}_{\mathrm{q}}$

Стабилишући момент је последица тежина које оптерећују потпорни зид. Начелно, то су следеће тежине: тежина зида, $\mathrm{G}_{z}$, тежина тла изнад задњег дела стопе, $\mathrm{G}_{\mathrm{t}}$, и тежина оптерећења на површини, $\mathrm{G}_{\mathrm{q}}$.

$\mathrm{M}_{\mathrm{stb}, \mathrm{d}}=0.9 \cdot\left(\mathrm{G}_{\mathrm{t}} \cdot \mathrm{e}_{\mathrm{t}}+\mathrm{G}_{\mathrm{z}} \cdot \mathrm{e}_{\mathrm{z}}\right)$

Улазни параметри: $\varphi ; \beta ; \alpha ; \delta ; \varphi$;

Коефицијент активног притиска тла:

$$
\mathrm{K}_{\mathrm{a}}=\frac{\sin ^{2} \cdot(\alpha+\varphi) \cdot \cos \delta}{\sin \alpha \cdot \sin (\alpha-\delta) \cdot\left[1+\sqrt{\frac{\sin (\varphi+\delta) \cdot \sin (\varphi-\beta)}{\sin (\alpha-\delta) \cdot \sin (\alpha+\beta)}}\right]^{2}}
$$

Анализа утицаја за потпорну конструкцију

Сопствена тежина потпорне конструкције

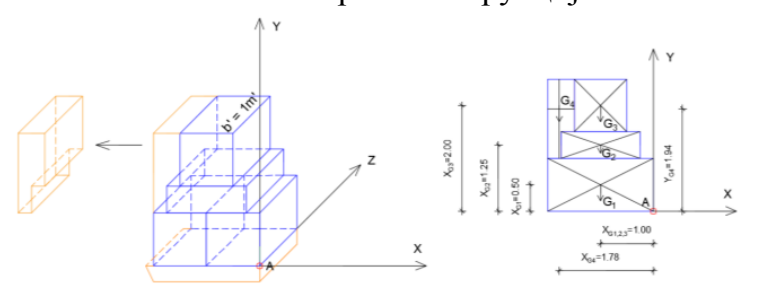

Слика 8 Сопствена тежина зида и део шљунка

$\mathrm{G}_{\mathrm{i}}=\mathrm{V}_{\mathrm{i}} \cdot \gamma_{\mathrm{i}}[\mathrm{kN}]$

Оптерећење од тла иза потпорне конструкције $\sigma=\gamma_{\check{s}} \cdot \mathrm{H} \cdot \mathrm{K}_{\mathrm{a}}\left[\mathrm{kN} / \mathrm{m}^{2}\right] ; \mathrm{E}_{\mathrm{a}}^{\gamma}=\frac{\mathrm{H} \cdot \sigma}{2}\left[\mathrm{kN} / \mathrm{m}^{2}\right]$

Хоризонтална компонента силе услед тежине тла иза зида:

${ }_{\mathrm{H}} \mathrm{E}_{\mathrm{a}}^{\gamma}=\mathrm{E}_{\mathrm{a}}^{\gamma} \cdot \cos \delta\left[\mathrm{kN} / \mathrm{m}^{\prime}\right] ; \mathrm{e}_{\mathrm{H}} \mathrm{E}_{\mathrm{a}}^{\gamma}=\frac{1}{3} \cdot \mathrm{H}[\mathrm{m}]$

Вертикална компонента силе услед тежине тла иза зида:

${ }_{\mathrm{v}} \mathrm{E}_{\mathrm{a}}^{\gamma}=\mathrm{E}_{\mathrm{a}}^{\gamma} \cdot \sin \delta\left[\mathrm{kN} / \mathrm{m}^{\prime}\right] ; \mathrm{e}_{\mathrm{v}} \mathrm{E}_{\mathrm{a}}^{\gamma}[\mathrm{m}]$

Корисно оптерећење -Коловоз:

$\mathrm{p}_{\mathrm{k}}=16.67[\mathrm{kPa}] ; \sigma_{\mathrm{k}}=\mathrm{p}_{\mathrm{k}} \cdot \mathrm{K}_{\mathrm{a}}\left[\mathrm{kN} / \mathrm{m}^{2}\right]$

$\mathrm{H}_{\mathrm{k}}=\mathrm{h}_{\mathrm{k}} \cdot \sigma_{\mathrm{k}}\left[\mathrm{kN} / \mathrm{m}^{2}\right] ; \mathrm{e}_{\mathrm{k}}=\frac{1}{2} \cdot \mathrm{h}_{\mathrm{k}}=[\mathrm{m}]$

Пешачка стаза: $\mathrm{p}_{\mathrm{ps}}=5.00 \mathrm{kPa} ; \sigma_{\mathrm{ps}}=\mathrm{p}_{\mathrm{ps}} \cdot \mathrm{K}_{\mathrm{a}}\left[\mathrm{kN} / \mathrm{m}^{2}\right]$

$\mathrm{H}_{\mathrm{ps}}=\mathrm{h}_{\mathrm{ps}} \cdot \sigma_{\mathrm{k}}\left[\mathrm{kN} / \mathrm{m}^{2}\right] ; \mathrm{e}_{\mathrm{ps}}=\frac{1}{2} \cdot \mathrm{h}_{\mathrm{ps}}[\mathrm{m}]$

Кохезија ; $=0.00 \mathrm{kPa}$

Табела -2 Парцијални коефицијенти ( препоручрне вредности ) за дејства, $\gamma_{F}-E Q U$

\begin{tabular}{|c|c|c|c|c|}
\hline \multirow{3}{*}{ Stalno dejstvo } & Nepovoljno & $r_{c o s t}$ & 1.1 & \\
\hline & Povoljno & $r_{\text {casto }}$ & 0.9 & (1.15) \\
\hline & Nepovolino & reate & 1.5 & (1.50) \\
\hline
\end{tabular}

Моменти савијања који дестабилишу потпорну конструкцију

$\mathrm{M}_{\mathrm{dst}, \mathrm{d}}=\gamma_{\mathrm{G}, \mathrm{dst}} \cdot\left[{ }_{\mathrm{H}} \mathrm{E}_{\mathrm{a}}^{\gamma} \cdot \mathrm{e}_{\mathrm{H}} \mathrm{E}_{\mathrm{a}}^{\gamma}\right]+\gamma_{\mathrm{Q}, \mathrm{dst}}\left[\mathrm{H}_{\mathrm{k}} \cdot \mathrm{e}_{\mathrm{k}}+\mathrm{H}_{\mathrm{ps}} \cdot \mathrm{e}_{\mathrm{ps}}\right]$,

$[\mathrm{kNm} / \mathrm{m}]$

Моменти савијања који стабилишу потпорну конструкцију

$\mathrm{M}_{\mathrm{stb}, \mathrm{d}}=\gamma_{\mathrm{G}, \mathrm{stb}} \cdot\left[\mathrm{G}_{1} \cdot \mathrm{X}_{\mathrm{G} 1}+\mathrm{G}_{2} \cdot \mathrm{X}_{\mathrm{G} 2}+\mathrm{G}_{3} \cdot \mathrm{X}_{\mathrm{G} 3}+\mathrm{G}_{4} \cdot \mathrm{X}_{\mathrm{G} 4}+{ }_{\mathrm{v}} \mathrm{E}_{\mathrm{a}}^{\gamma} \cdot \mathrm{e}\right.$ $\left.{ }_{\mathrm{v}} \mathrm{E}_{\mathrm{a}}^{\gamma}\right],[\mathrm{kNm} / \mathrm{m}]$

$\mathrm{M}_{\mathrm{stb}, \mathrm{d}}>\mathrm{M}_{\mathrm{dst}, \mathrm{d}}=134.1578 \mathrm{kNm} / \mathrm{m}^{\prime}>48.7786 \mathrm{kNm} / \mathrm{m}^{\prime}-$

резултат добијен израдом мастер рада.

$\rightarrow$ Потпорна конструкција је стабилна на претурање.

\section{2 Контрола стабилности на клизање}

Сопствена тежина габионске конструкције је већ израчуната. Из горе поменутог да се прорачун врши користећи карактеристичне вредности, односно да се тек на крају прорачуна примењују коефицијенти следи да је коефицијент активног притиска, као и утицаји на потпорну конструкцију исти каопри контроли стабилности на претурање

За разлику од претурања, контрола стабилности зида на клизање се доказује за гранична стања носивости лома услед великих деформација тла, GEO.

Потребно је да буде задовољена следећа релација:

$\mathbf{T}_{\mathrm{d}} \leq \mathbf{T}_{\text {rd }}$

односно прорачунска вредност дејства/утицаја треба да буде мања или једнака прорачунској отпорности на клизање, где је прорачунска отпорност на клизање дата изразом:

$\mathbf{T}_{\mathbf{r d}}=\frac{\mathbf{N}_{\mathrm{d}} \tan \varphi \prime_{\mathbf{d}}}{\gamma_{\mathrm{R}, \mathrm{H}}}$

Утицај је смичућа сила Т у темељној спојници која тежи да покрене конструкцију да клиза, док је отпорност на клизање представљена силом трења која зависи од величине нормалне силе и угла трења (угао трења-tan $\varphi_{d}^{\prime}$ )

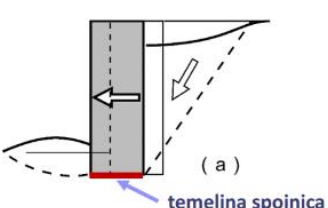

Слика 9 Линија клизања зида

Дестабилишућим се јављају хоризонталне силе (или хоризонталне пројекције косих): притиска услед тежине тла, $\mathrm{P}_{\mathrm{t}}$, и притиска услед оптерећења на површини, $\mathrm{P}_{\mathrm{q}}$, умножене парцијалним коефицијентима за дејства.

Клизању се супротставља, као стабилишућа хоризонтална сила, трење које се реализује на контакту између стопе зида и тла испод. Хоризонтална стабилишућа сила се одређује за овако анализиране тежине:

$\mathrm{H}_{\mathrm{stb}, \mathrm{d}}\left(\mathrm{T}_{\mathrm{rd}}\right)=\mu \cdot \sum G_{i}=\mu \cdot\left(G_{t}+G_{z}\right)$
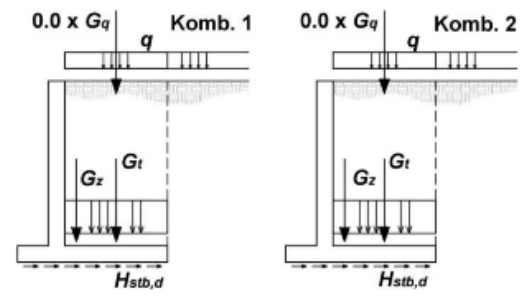

Слика 11 Стабилишућа сила клизања 
Табела 3 Парцијални коефиијенти за дејства , $\gamma_{F}$, или утицаје од дејстава, $\gamma_{\mathrm{E}}-\mathrm{STR} / \mathrm{GEO}$

\begin{tabular}{|c|c|c|c|c|}
\hline & & & Al & \\
\hline \multirow{2}{*}{ Stalno dejstvo } & Nepovoljno & \multirow{2}{*}{$r c$} & 1.35 & 1.00 \\
\hline & Povoljno & & 1.00 & 1.00 \\
\hline \multirow{2}{*}{ Povremeno dejstvo } & Nepovoljno & \multirow{2}{*}{ re } & 1.50 & 1.30 \\
\hline & Povoljno & & 0.00 & 0.00 \\
\hline
\end{tabular}

Хоризонталне силе које дестабилишу потпорну конструкцију

Hdst,d $=\gamma \mathrm{G}, \mathrm{dst} \cdot[\mathrm{HEa} \gamma]+\gamma \mathrm{Q}, \mathrm{dst} \cdot[\mathrm{Hk} \cdot+\mathrm{Hps}]\left[\mathrm{kN} / \mathrm{m}^{\prime}\right]$

Хоризонталне силе које стабилишу потпорну

конструкцију

Hstb,d $=\gamma \mathrm{G}, \mathrm{stb} \cdot[\Sigma \mathrm{Gi}+\mathrm{VEa} \gamma] \cdot \mu$

$=\gamma \mathrm{G}, \mathrm{stb} \cdot[\mathrm{G} 1+\mathrm{G} 2+\mathrm{G} 3+\mathrm{G} 4+\mathrm{VEa} \gamma] \cdot \mu\left[\mathrm{kN} / \mathrm{m}^{\prime}\right]$

Табела -4 Парцијални коефицијенти за отпоре, $\gamma_{\mathrm{R}, \mathrm{y}}$ плитком темељењу - GEO

\begin{tabular}{|c|c|c|c|c|}
\cline { 3 - 5 } \multicolumn{2}{c|}{} & R1 & R2 & R3 \\
\hline Slom u pod-tlu & $\gamma_{R, v}$ & 1.00 & 1.40 & 1.00 \\
\hline Klizanje & $\gamma_{R, h}$ & 1.00 & 1.10 & 1.00 \\
\hline
\end{tabular}

$\frac{H_{s t b, d}}{\gamma_{R, H}}[\mathrm{kN} / \mathrm{m}]^{\prime} ; \mathrm{H}_{\mathrm{stb}, \mathrm{d}}>\mathrm{H}_{\mathrm{dst}, \mathrm{d}}=64.0489 \mathrm{kN} / \mathrm{m}^{\prime}>62.3246$

$\mathrm{kN} / \mathrm{m}$ - резултат добијен израдом мастер рада

$\rightarrow$ Потпорна конструкција је стабилна на клизање.

3.3 Контрола напона у тлу на контакној површини

Контрола напона у контактној површини се, такође, спроводи директном методом за гранична стања носивости - лома услед великих деформација тла, GEO.

Дистрибуција контактних напрезања се одређује уз претпоставку правоугаоне дистрибуције на делу контактне површи. Утицаје сводимо на тежиште темељне спојнице и прорачунске вредности добијамо користећи парцијалне факторе сигурности за неповољна дејства.

Потребно је да буде задовољена следећа релација:

$\mathbf{V}_{\mathbf{d}} \leq \mathbf{R}_{\mathbf{d}} \rightarrow \mathbf{R}_{\mathbf{d}} / \mathbf{A}^{\prime}=\mathbf{q}_{\mathbf{R d}}$, односно прорачунска вредност дејства треба да буде мања или једнака прорачунској смичућој отпорности тла.

Приликом контроле на претурање и клизање је израчуната сопствена тежина зида, као и утицаји на габионску конструкцију

Контрола напона у тлу за групу

коефицијената:A1+M1+R2

Нормална сила: $\mathrm{V}_{\mathrm{d}}=\gamma_{\mathrm{G}, \mathrm{stb}} \cdot \mathrm{G}+\gamma_{\mathrm{G}, \mathrm{dst}} \cdot\left[\mathrm{v}_{\mathrm{a}} \mathrm{E}^{\gamma}\right],[\mathrm{kN} / \mathrm{m}]$

Момент претурања: $M_{\mathrm{ad}}=\gamma_{\mathrm{G}, \mathrm{stb}} \cdot\left[\mathrm{G} \cdot \mathrm{X}_{\mathrm{G}}\right]+\gamma_{\mathrm{G}, \mathrm{dst}}\left[\mathrm{V}_{\mathrm{a}} \mathrm{\gamma}^{\gamma_{\mathrm{V}}} \mathrm{e}_{\mathrm{V}} \mathrm{E}_{\mathrm{a}}{ }^{\gamma}\right.$ $\left.{ }_{\mathrm{H}} \mathrm{E}_{\mathrm{a}}^{\gamma} \cdot \mathrm{e}_{\mathrm{H}} \mathrm{E}_{\mathrm{a}}^{\gamma}\right]-\gamma_{\mathrm{Q}, \mathrm{dst}}\left[\mathrm{H}_{\mathrm{k}} \cdot \mathrm{e}_{\mathrm{k}}+\mathrm{H}_{\mathrm{ps}} \cdot \mathrm{e}_{\mathrm{ps}}\right],[\mathrm{kNm} / \mathrm{m}]$

Положај силе х: $\mathrm{x}=\frac{\mathrm{M}_{\mathrm{d}}}{\mathrm{v}_{\mathrm{d}}}[\mathrm{m}] \rightarrow \mathrm{e}=\frac{\mathrm{B}}{2}-\mathrm{x}[\mathrm{m}]<\frac{\mathrm{B}}{6}$

Активна ширина стопе $\mathrm{B}^{\prime}: \mathrm{B}^{\prime}=2 \cdot \mathrm{x}[\mathrm{m}]$

Напон у тлу: $\mathrm{q}_{\mathrm{Ed}}=\frac{\mathrm{v}_{\mathrm{d}}}{\mathrm{B}]}\left[\mathrm{kN} / \mathrm{m}^{2}\right]$

Granična nosivost temeljnog tla $u$ dreniranim uslovima:

Улазни подаци $\gamma_{\mathrm{pg}}[\mathrm{kN} / \mathrm{m} 3] ; \alpha=0^{\circ}$ - Зид има равно тло, не стоји под нагибом ; $\varphi\left[^{\circ}\right] ; \mathrm{c}[\mathrm{kPa}]$

Прорачунска носивост је дата изразом:

$\mathrm{q}_{\mathrm{rd}}=\frac{0.5 \gamma_{\mathrm{d}} \mathrm{B} / \mathrm{N}_{\gamma} \mathrm{s}_{\gamma} \mathrm{i}_{\gamma} \mathrm{b}_{\gamma}+\mathrm{c}_{\mathrm{d} /} \mathrm{N}_{\mathrm{c}} \mathrm{s}_{\mathrm{c}} \mathrm{i}_{\mathrm{c}} \mathrm{b}_{\mathrm{c}}+\gamma_{\mathrm{d}} \mathrm{D}_{\mathrm{f}} \mathrm{N}_{\mathrm{q}} \mathrm{s}_{\mathrm{q}} \mathrm{i}_{\mathrm{q}} \mathrm{b}_{\mathrm{q}}}{\gamma_{\mathrm{R}, \mathrm{V}}}$

Фактори носивости:

$\mathrm{N}_{\mathrm{q}}=\mathrm{e}^{\pi \operatorname{tg} \varphi^{\prime}} \times \operatorname{tg}^{2} \times(45+\varphi / 2)$

$\mathrm{N}_{\mathrm{c}}=\left(\mathrm{N}_{\mathrm{q}}-1\right) \times \operatorname{ctg} \varphi^{\prime} ; \mathrm{N}_{\gamma}=2 \times\left(\mathrm{N}_{\mathrm{q}}-1\right) \times \operatorname{tg} \varphi^{\prime}$

Фактор нагиба контактне површи темеља:

$\mathrm{b}_{\mathrm{q}}=\mathrm{b}_{\gamma}=\left(1-\alpha \times \operatorname{tg} \varphi^{\prime}\right)^{2} ; \mathrm{b}_{\mathrm{c}}=\mathrm{b}_{\mathrm{q}}-\frac{1-\mathrm{b}_{\mathrm{q}}}{\mathrm{N}_{\mathrm{c}} \times \operatorname{tg} \varphi}$

Фактори за облик темељне површине:
$\mathrm{S}_{\mathrm{q}}=1+\frac{\mathrm{B} \text { 国 }}{\mathrm{L}^{\mathrm{g}}} \times \sin \varphi^{\prime}$, за правоугаон облик;

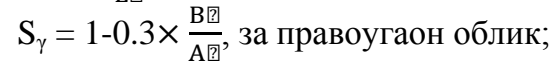

$\mathrm{S}_{\mathrm{c}}=\frac{\mathrm{S}_{\mathrm{q} \times \mathrm{N}_{\mathrm{q}}-1}}{\mathrm{~N}_{\mathrm{q}}-1}$, за правоугаони, квадратни и кружни облик

Фактори за нагиб оптерећења, услед хоризонталне силе $\mathrm{H}$

$\mathrm{i}_{\mathrm{q}}=\left(1-\frac{\mathrm{H}}{\mathrm{V}+\mathrm{A} \operatorname{0} \times \mathrm{c} \times \operatorname{ctg} \varphi}\right)^{\mathrm{m}} ; \mathrm{i}_{\mathrm{c}}=\mathrm{i}_{\mathrm{q}}-\frac{1-\mathrm{i}_{\mathrm{q}}}{\mathrm{N}_{\mathrm{c}} \times \operatorname{tg} \varphi}$

$\mathrm{i}_{\gamma}=\left(1-\frac{\mathrm{H}}{\mathrm{V}+\mathrm{A} \text { 目 } \times \mathrm{c} \times \operatorname{ctg} \varphi}\right)^{\mathrm{m}+1}$

где je: $\mathrm{m}_{\mathrm{B}}=\frac{2+\mathrm{B} \text { 回 } / \mathrm{L}}{1+\mathrm{B} \text { 回 } / \mathrm{L}}$

$\mathrm{q}_{\mathrm{Ed}} \leq \mathrm{q}_{\mathrm{Rd}} \rightarrow 72.33 \mathrm{kN} / \mathrm{m}^{2} \leq 73.8060 \mathrm{kN} / \mathrm{m}^{2}$ - резултат добијен израдом мастер рада.

$\rightarrow$ Услов да прорачунска вредност дејства треба да буде мања или једнака прорачунској смичућој отпорности тла - ЗАДОВОљЕН

$\mathrm{R}_{\mathrm{d}} / \mathrm{A}^{\prime}=\mathrm{q}_{\mathrm{Rd}}, \rightarrow \mathrm{Rd}=\mathrm{q}_{\mathrm{Rd}} \times \mathrm{A}^{\prime} \rightarrow \mathrm{Rd}=73.80 \times 1.7210=127.0098$

$\mathrm{V}_{\mathrm{d}} \leq \mathrm{R}_{\mathrm{d}}=124.41 \mathrm{kN} / \mathrm{m}^{\prime} \leq 127.01 \mathrm{kN} / \mathrm{m}^{2}$

$\rightarrow$ Услов да прорачунска вредност дејства треба да буде мања или једнака прорачунској смичућој отпорности тла - ЗАДОВОљЕН

\section{4. ЗАКЉУЧАК}

У овиру мастер рада је приказана методологија прорачуна габионског зида према еврокоду 7. Теоријски су описане габионске конструкције, статички притисци тла, еврокод 7( геотехнички прорачун, гранична стања носивости, пројектни приступи и др.) што је предуслов познавања да би се вршила контрола стабилности габионског зида. Прорачун је рађен ручно, као и у софтверу Гео 5, у оба случаја резултати су били успешни. Габионски зид је задовољио услове приликом контроле стабилности на клизање, претурање, напрезања тла у контактној површини, носивости тла.

\section{5. ЛИТЕРАТУРА}

[1] Бетонске конструкције инжењерских објеката, Зоран Брујић

[2] Прилог изради националног анекса еврокоду 7 - из аспекта потпорних зидова , (Зоран Бонић i dr.)

[3] Механика тла, М. Максимовић

[4] Европска техничка регулатива у грађевинарству, др Ива Деспотовић

\section{Kratka biografija:}

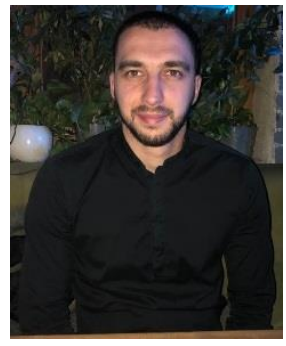

Петар Јелић, Чачак, Србија 11.04.1993. год., Основна школа „Доситеј Обрадовић”, село Ратина у Краљеву, средња школа Гимназија, Краљево. Октобра 2012. год. уписује основне студије на Факултету техничких наука из области Грађевинарства, 2018. године стиче звање дипломираног грађевинског инжењера на одсеку за путеве, железнице и аеродроме. Мастер рад на Факултету техничких наука из области одабрана поглавља из планирања и пројектовања градских саобраћајница одбранио је у октобру 2020. године. 